\title{
Learning Lessons from Peace Operations in Africa
}

\author{
Paul D. Williams
}

\section{INTRODUCTION}

This chapter reflects on the experiences of more than fifty peace operations deployed in Africa during the twenty-first century in order to identify some of the most important generic lessons and potential new approaches that have emerged. These peace operations varied across several dimensions with each mission operating in a distinct set of circumstances to achieve a unique set of mandated tasks. Consequently, any attempt to draw generic lessons without a concomitant focus on missionspecific lessons should not be treated as definitive. Nevertheless, there is some value in trying to move beyond mission-specific analysis and draw broader conclusions, as this chapter seeks to do.

For the purposes of this chapter, I define peace operations broadly as the expeditionary use of uniformed personnel (troops, military observers/experts, and police), with or without a United Nations (UN)

P. D. Williams $(\bowtie)$

Security Policy Studies, The George Washington University, Washington, DC, USA

e-mail: pauldw@email.gwu.edu

(C) The Author(s) 2021

T. McNamee and M. Muyangwa (eds.),

The State of Peacebuilding in Africa, https://doi.org/10.1007/978-3-030-46636-7_2 
mandate, but with an explicit mandate to assist in the prevention of armed conflict by supporting a peace process; serve as an instrument to observe or assist in the implementation of ceasefires or peace agreements; or enforce ceasefires, peace agreements, or the will of the UN Security Council in order to build stable peace. ${ }^{1}$ This excludes what the UN calls "special political missions" as well as "collective defense operations" (such as the Ethiopian intervention in Somalia in 2006) and humanitarian military interventions (such as the NATO-led operation in Libya in 2011).

This chapter starts by providing an overview of the main trends in peace operations in Africa focusing on the record number of missions and peacekeepers deployed; the wide range of mandated tasks given to them; the prominence of civilian protection issues; the intensifying debates over the use of force; and the rise of "partnership peacekeeping." The second section summarizes the major generic lessons that can be identified from these operations. These include the need to ensure peace operations are part of a viable political strategy aimed at conflict resolution; that means and ends are in tune; that a capabilities and effects-based approach to force generation is superior to a numbers-centric approach; and maintaining legitimacy among key international and local audiences can significantly enhance the prospects for success. The concluding section offers six recommendations for improving the performance of peace operations in these areas.

\section{Trends in Peace Operations in Africa}

Africa has witnessed more than 50 peace operations during the twentyfirst century. ${ }^{2}$ Several major trends have emerged: the number of peacekeepers, missions, and budgets has increased significantly with African states and the African Union (AU) playing increasingly important roles but the UN remaining the single most prominent actor; most missions have been given extremely wide-ranging and complex mandates; civilian protection has often risen to prominence among these tasks; disagreement persists over when peacekeepers should use military force; and "partnership peacekeeping" has become the norm in the continent. Each of these characteristics will be discussed more fully below. 


\section{Record Levels}

First, the twenty-first century has witnessed significant growth in the number, size, and cost of peace operations in Africa (see Fig. 2.1). Since 2002, there have been at least 14 missions across the continent in each calendar year. By the end of 2016, there were over 115,000 uniformed peacekeepers in Africa: over 80,000 from the UN (see Fig. 2.2); over 20,000 from the AU; and approximately another 15,000 in regional and other operations. More than 11,000 were police officers. These figures do not include the estimated 15,500 additional civilian personnel in UN and AU peace operations. The cost of these operations reflects the fact that many of these personnel have deployed into often difficult, remote terrain and are required to come with large numbers of vehicles and other major equipment items and life support systems.

While the UN has deployed the most peacekeepers, there has been a major increase in the number of African personnel in these missions (nearly half of all UN uniformed peacekeepers are African), as well as a growing number of missions led or authorized by African regional

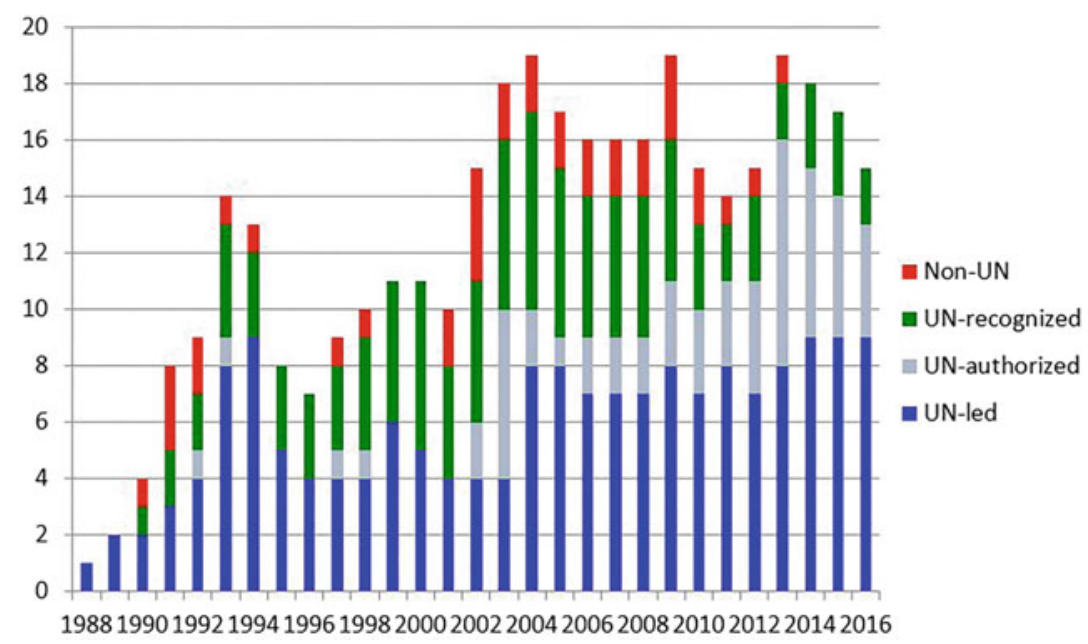

Fig. 2.1 Number and types of peace operations in Africa, 1988-2016 (Source Adapted and updated from Alex J. Bellamy and Paul D. Williams, "Trends in Peace Operations, 1947-2013," in The Oxford Handbook of United Nations Peacekeeping Operations, ed. Koops et al. [Oxford University Press, 2015]) 


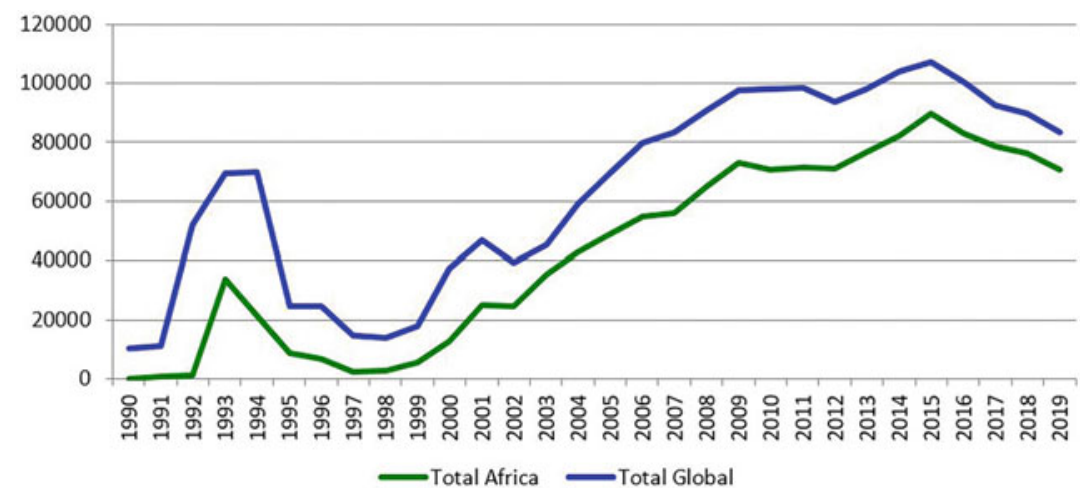

Fig. 2.2 UN uniformed personnel worldwide and in Africa 1990-2019 (Source Adapted by author)

organizations. In the 1990s and early 2000s, Africa's regional economic communities (RECs) deployed most missions. Since 2004, however, the AU has played the central role, authorizing the deployment of approximately 70,000 uniformed peacekeepers in 12 missions (see Fig. 2.3). ${ }^{3}$ However, there were three important caveats to this trend. First, these deployments required considerable external assistance. Second, the AU

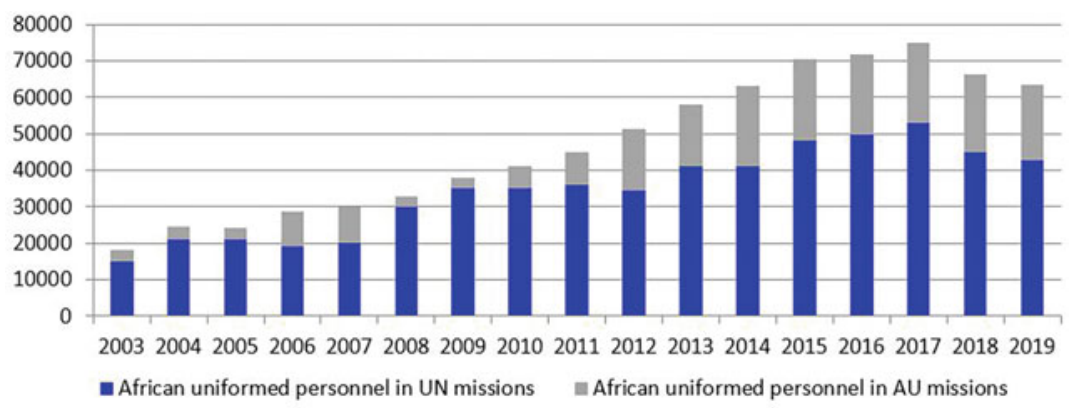

Fig. 2.3 Uniformed personnel deployed by African Union member states in UN and AU missions (31 July annual) (Source Providing for peacekeeping database, November 1990-present, International Peace Institute and George Washington University, http://www.providingforpeacekeeping.org/con tributions, and author's calculations) 
struggled to deploy sufficient numbers of police and other civilian experts on its missions. And, since 2003, the majority of African peacekeepers came from roughly one-fifth of the AU's members, particularly Burundi, Egypt, Ethiopia, Ghana, Kenya, Nigeria, Rwanda, Senegal, South Africa, Tanzania, and Uganda.

\section{Wide-Ranging Mandates}

The second major trend has been the growing list of mandated tasks given to peace operations in Africa, which range from observing ceasefires; protecting humanitarian relief supplies; supporting disarmament, demobilization, and reintegration (DDR) programs; strengthening the rule of law and public security; supporting weak governments, including through extending state authority and security sector reform (SSR); protecting civilians and electoral processes; stabilization; counterinsurgency; to warfighting. Importantly, each set of tasks generally requires different force requirements, capabilities, and training, but this has not always been catered for during the force generation process. There was also a notable expansion in the importance placed on having police officers deploy in these missions to perform a variety of tasks related to strengthening the rule of law and public security.

Put bluntly, most peace operations in twenty-first century Africa were asked to help build institutions of liberal democratic governance in some of the continent's poorest and war-torn states. For their critics, these mandates had become too broad and unrealistic given the few incentives for conflict parties in Africa to build genuinely liberal institutions.

One problem was the lack of clarity over how peacekeepers should fulfill certain objectives and the meaning of key terms. As the head of the UN's Department of Peacekeeping Operations observed, not only were mission mandates "more complex than ever" but, "there remains a lack of consensus on how certain mandate tasks should be fulfilled." 4 Part of the problem was that even basic terminology used in mandates was often unclear. Peacekeepers were often told to "assist" authorities and "support" processes using "all necessary measures" without being given further specific instructions. "Peacebuilding" and "civilian protection" (see below) were another two widely debated and confusing concepts. The vague nature of such terms encouraged the unhelpful tendency for different national contingents within a peace operation to sometimes interpret their mandates in different ways. 
Another problem stemmed from peacekeepers being given contradictory tasks. In both the Democratic Republic of the Congo (DRC) and South Sudan, for example, peacekeepers were told to help host governments extend their authority across the country and protect civilians-in the full knowledge that the government's armed forces were among the principal perpetrators of violence against civilians. Peacekeepers had the legal right to use deadly force against host government forces that committed war crimes against local civilians. However, in practice, things were rarely that simple, either because government forces outnumbered the peacekeepers or because acting against the host government might cause it to expel the peace operation.

A third mandate problem was the tendency to produce long lists of tasks without providing criteria to clearly prioritize among them. The initial mandate for the United Nations Mission in South Sudan (UNMISS), for example, contained a list of well over 40 different tasks with priority given to assisting with state-building and civilian protection, tasks that require very different capabilities and approaches and neither of which have a quick exit strategy. By 2018, the UN Secretary-General was telling the Council that UNMISS "cannot possibly implement 209 mandated tasks." ${ }^{5}$ On the positive side, the UN's most recent operation in Africa, the United Nations Multidimensional Integrated Stabilization Mission in the Central African Republic (the mission is known by its French acronym, MINUSCA, the country is known by its English acronym, CAR), tried to overcome this problem by introducing the notion of "urgent temporary measures," i.e., those tasks that should form the initial priority. The African Union Mission in Somalia (AMISOM) also tried to prioritize tasks-but ultimately suffered from too many priorities, with its post-2016 mandate identifying three strategic objectives, four priority tasks, and six essential tasks. ${ }^{6}$ Importantly, two high-level panels on UN peace operations had called for peacekeeping mandates to be sequenced. In 2000, the Brahimi Report called for mandates to remain in draft form until the UN's member states provided the requisite resources. ${ }^{7}$ In 2015, the High-Level Independent Panel on Peace Operations (HIPPO) called for a "two-stage sequenced mandating process" with fewer priorities that would allow missions to develop over time, rather than trying to do everything at once. ${ }^{8}$ 


\section{Protecting Civilians}

Arguably one of the most important mandated tasks in twenty-first century missions has been protecting civilians. ${ }^{9}$ Although many peace operations in Africa grappled with the problems of civilian protection throughout the 1990s, it was not until 1999 that all UN multidimensional peacekeeping operations in Africa included some explicit element of civilian protection in their mandates. Since 2003, the European Union (notably Operation Artemis and European Union Force [EUFOR] missions in Chad and CAR) and the AU (notably in its missions in Darfur, Mali, and CAR) have also given some of their operations civilian protection tasks. In part, the surge of civilian protection mandates stemmed from the recognition that local civilians usually judged a mission's effectiveness on how well it protected them rather than other more technical criteria. But it was also because several UN high-level inquiries concluded that the inability to distinguish between victims and aggressors and the failure to protect the former was highly damaging to the UN's legitimacy. 10

But, even when civilian protection mandates were issued to UN peacekeepers, they came with geographic, political, and operational caveats. First, peacekeepers were supposed to protect civilians "without prejudice to responsibility of host nation"-despite the armed forces of some host governments being major perpetrators of civilian harm. Second, peacekeepers were only supposed to protect civilians within their existing "capabilities and areas of deployment." In one sense, this sensibly left key decisions about implementing this mandate to force commanders on the ground. But, on the other hand, it often encouraged peacekeepers not to use force to protect civilians, but rather to remain in their bases which, in turn, encouraged endangered civilians to flock to them. ${ }^{11}$ Third, the focus was usually narrowed to protecting only those civilians "under imminent threat of violence" which, by definition, is a point at which it is too late for peacekeepers to succeed. In response to this problem, the UN started using the phrase "threat of violence" without the reference to "imminent" and emphasizing that peacekeepers should actively deter violence against civilians. ${ }^{12}$

Even with these caveats, UN peacekeepers struggled with how to translate this aspirational concept into practical military and policing tasks that could be trained and implemented in the field. It took the UN over 
a decade to develop guidelines and training regimes on how its peacekeepers could best operationalize this concept in the field. ${ }^{13}$ A big part of the problem was that UN peacekeeping missions had traditionally not been permitted to use intelligence-gathering capabilities because of political disputes within the UN General Assembly and Security Council. And yet, it was impossible for a mission with limited resources to respond effectively to threats against civilians if it did not have access to accurate and timely intelligence about the sources of such threats. As a consequence, some operations, especially the United Nations Organization Stabilization Mission in the Democratic Republic of the Congo (MONUSCO) and UNMISS, began to innovate their own responses to overcoming this challenge, including by creating Joint Protection Teams, Community Liaison Assistants, and Community Alert Networks. The formation of the All Sources Information Unit (ASIFU) in MINUSMA's early years was the closest a UN peacekeeping operation has come to developing an official intelligence-gathering capability.

Although most media reporting focused on the failures of peacekeepers to protect civilians, even in truly dire circumstances the presence of peacekeepers usually made the overall situation for civilians better, not worse. ${ }^{14}$ The basic problem was that there was only so much even well-resourced peacekeepers could do. As one analysis correctly observed, peacekeeping operations could not "protect everyone from everything," nor could they "operate without some semblance of a 'peace to keep' or halt determined belligerents wholly backed by a state." 15

\section{Using Force}

The fourth trend in peace operations in Africa was persistent debate over when peacekeepers should use military force beyond self-defense. This raised fundamental questions about the nature and limits of peace operations and the efficacy of using multinational forces with large numbers of contributing countries to wield military power effectively. In twenty-first century Africa, there have been several examples of peace operations coming close to war-fighting at the tactical level against particular "spoiler" groups, including in Sierra Leone, the DRC, Côte d'Ivoire, Somalia, Mali and Central and West Africa against the Lord's Resistance Army (LRA) and Boko Haram. While the AU had no qualms about using a peace operation to engage in war-fighting, the UN's basic 
principles of peacekeeping - consent of the main conflict parties; impartiality; and minimum use of force except in self-defense and defense of the mandate-made it much less common in UN-led operations. The formation of the Force Intervention Brigade (FIB) within MONUSCO in 2013 generated a novel lexicon from the UN Security Council, which mandated it to "neutralize armed groups" by carrying out "targeted offensive operations." $" 16$

When the UN Security Council authorized proactive military force beyond self-defense, it was usually in the name of either protecting civilians or defeating spoiler groups such as M23 in the DRC. The AU also regularly authorized its forces to protect civilians and defeat particular spoilers, notably in the Comoros, Somalia, Mali, CAR, and in its multinational task forces authorized to fight against the LRA and Boko Haram.

For the UN, this type of combat operations raised questions about whether it could remain an impartial actor. The UN's response was, "yes, it could," because impartiality permitted the use of force against recalcitrant parties: "Just as a good referee is impartial, but will penalize infractions, so a peacekeeping operation should not condone actions by the parties that violate the undertakings of the peace process or the international norms and principles that a United Nations peacekeeping operation upholds." 17 However, these nuances were clearly lost on some armed groups who did not view UN peacekeepers as impartial and targeted them accordingly.

A key question is whether this was a sensible policy for the UN to pursue given the many difficulties involved with command and control in its peacekeeping operations, which left them poorly designed to fight wars. Moreover, most UN contributing countries did not sign up to fight wars or undertake proactive combat operations against determined adversaries. As a result of these inherent limitations, the latest HIPPO concluded that "extreme caution must guide any call for a United Nations peacekeeping operation to undertake enforcement tasks and that any such mandated task should be a time-limited, exceptional measure." 18 Nor, it wrote, should UN peacekeepers conduct counter-terrorism operations. ${ }^{19}$ 


\section{Partnership Peacekeeping}

The last major trend analyzed here is that "partnership peacekeeping" has become the norm in Africa. This entails collaboration on operations between two or more multilateral institutions and/or various bilateral actors. Several factors have driven this trend, including widespread recognition that no single actor can cope with Africa's security challenges alone and that different actors bring comparative advantages to peace operations. As Fig. 2.1 shows, however, most peace operations have been authorized or supported by the UN Security Council, demonstrating the enduring significance of the UN brand and legitimacy. In Africa, the central partnerships involve relations among the UN, the AU, the RECs, the European Union, and important bilateral actors-principally France, the United States, and Britain.

In Africa, partnership peacekeeping has taken several different forms. There have been sequenced operations, as in Mali, Burundi, and CAR, in which responsibility transitions from one set of actors to another, usually from African organizations to the UN. There have been parallel operations where multiple missions coexist simultaneously within the same theater, as in the DRC, Côte d'Ivoire, and CAR. The UN has also provided a variety of support packages to regional missions using funds from its assessed contributions to peacekeeping, as in Darfur and Somalia. There has also been one joint hybrid mission between the UN and the AU in Darfur, Sudan, the African Union-United Nations Mission in Darfur (UNAMID).

\section{Lessons IDENTIFIEd From PeACE Operations in Africa}

What are the major generic lessons that can be identified from the numerous peace operations deployed in Africa during the twenty-first century? This section briefly summarizes four such lessons: the need to ensure peace operations are part of a viable strategy of conflict resolution; that means and ends are kept in tune; that a capabilities and effects-based approach to force generation is superior to a numbers-centric approach; and maintaining legitimacy among key international and local audiences can significantly enhance the prospects for success. 


\section{The Primacy of Politics}

Arguably the most important lesson is that successful peace operations are those that ensure what the HIPPO called "the primacy of politics." ${ }^{20}$ In essence, peace operations are political instruments, sometimes backed by a security guarantee in the form of troops. They are not the same thing as a political strategy aimed at resolving the crisis in question. Instead, as the HIPPO report emphasized, "UN peace operations must be deployed as part of a viable process" to achieve a political settlement to the crisis in question. The same goes for other forms of peace operations too. "Lasting peace," the report concluded, "is not achieved nor sustained by military and technical engagements, but through political solutions." It is, therefore, politics, not military force that is the peacekeeper's primary weapon. As the HIPPO report put it, "political solutions, not military force, are the true force multipliers" for peacekeepers. ${ }^{21}$

A related lesson is that because political primacy ultimately rests with national actors, peacekeepers can only support peace processes; they cannot impose sustainable peace in the absence of local willingness to do so. If the UN, the AU, or other actors deploy peacekeepers without a political pathway to peace, the best-case scenario is that they limit some of the worst negative consequences of the armed conflict in question. But it would be naïve to believe that peacekeepers can deliver peace in a context in which important local actors want war. Political dynamics in New York and Addis Ababa will often push politicians to deploy peacekeepers even in the absence of a viable strategy of conflict resolution, but this only adds to the imperative to learn this particular lesson.

\section{Ends and Means in Tune}

A second key lesson is that peace operations will likely fail when their means and ends are not in tune, i.e., peacekeepers are not given the resources necessary to achieve their goals. There are at least two dimensions to this lesson. First, the goals of the operation should be set out in clear, credible, and flexible mandates, and peacekeepers given appropriate Rules of Engagement. Second, once mandated, policymakers must prevent large vacancy rates i.e., discrepancies between the authorized force levels and the actual numbers and types of personnel on the ground (see below on force generation). Such personnel gaps not only hamper a 
mission's ability to take advantage of the so-called "golden hour" immediately after the cessation of fighting but also signal to the conflict parties a lack of political will within the authorizing organizations.

Large vacancy rates have damaged the performance of several peace operations, perhaps most notably UNAMID in Sudan and AMISOM in Somalia. This issue is not only important at the mission start-up phase but also when mandates are changed in response to developing circumstances and alter the mission's force strength and/or capabilities. Unfortunately, mandates have often been revised without providing peacekeepers with the necessary additional or different resources. Authorized reinforcements, for example, have become notorious for not arriving as planned, as occurred in eastern DRC in 2008 and South Sudan in early 2014. In perhaps the worst example, it took until December 2016 for AMISOM to receive its first three military helicopters after the UN Security Council authorized twelve of them in 2012 .

\section{Effective Force Generation}

A third, and related, lesson is that without effective force generation processes peace operations will struggle to achieve success. ${ }^{22}$ More specifically, it is clear that a capabilities and effects-based approach to force generation is superior to the traditional numbers-centric approach. ${ }^{23}$ Once a peace operation has been established, the authorizing institution must ensure the relevant peacekeepers and capabilities are generated rapidly. Each peace operation requires a unique combination of force requirements and capabilities. Most of these must come from voluntary contributions from states since most international organizations lack permanent armed forces or police.

The UN made significant progress in 2015, when it established the new Strategic Force Generation and Capability Planning Cell to play matchmaker between the UN and its member states who contribute to peace operations. There is also a new Peacekeeping Capability Readiness System to coordinate how and where member states can pledge military, police, and other civilian personnel to participate in UN missions. ${ }^{24}$ In addition, high-level political attention at the UN has been maintained by a series of peacekeeping leaders' summits and defense ministerials in 2014, 2015,2016 , and 2017, at which UN member states have pledged over 50,000 uniformed peacekeepers and a wide range of assets and enablers. 
Past experiences show that effective force generation (whether at the $\mathrm{UN}, \mathrm{AU}$, or elsewhere) is more likely with a broad pool of potential contributing states upon which to draw. ${ }^{25}$ Without a broad pool of contributors, authorizing institutions are unable to be very selective when assembling their peace operations and instead have to rely on what capabilities are available rather than what is required for the job. In Africa, particularly important and persistent gaps in the force generation process have included a dearth of female peacekeepers; French-speakers; police and other civilian experts; and a wide range of mobility vehicles and enabling units (especially medical, engineering, and logistics).

\section{Ensure Accountability}

A fourth key, generic lesson is that peace operations are less likely to succeed if they do not maintain legitimacy among key international and local audiences. This is often directly connected to ensuring that peacekeepers remain accountable both to their international bosses and the local populations they are supposed to serve. ${ }^{26}$ When peace operations are dependent on local support for their legitimacy and effectiveness, misconduct (including causing harm to civilians, engaging in sexual exploitation and abuse, or trafficking in illicit goods) can have negative strategic effects. Indeed, misconduct by peacekeepers can damage the reputation of both the particular mission as well as peacekeeping as a whole.

\section{Key ReCOMMENDATIONS}

In light of the preceding trends and major generic lessons identified from peace operations in twenty-first century Africa, this concluding section briefly sketches six recommendations intended to enhance the effectiveness of peace operations.

1. Enbance peacemaking capabilities. In order to create the impression that they are engaged in meaningful responses to crises, political leaders in New York, Addis Ababa, and elsewhere are likely to persist in deploying peace operations to African crises in the absence of a viable strategy of conflict resolution. Assuming this trend is likely to continue, advocates of more effective peace operations should push to invest more resources in developing better international mediation and peacemaking capabilities, including ensuring the full 
development of the AU's new Mediation Support Unit. It is the failure to resolve Africa's crises through peacemaking that has placed an impossible burden on peacekeepers.

2. Clarify the core tasks of peace operations. Political leaders in New York and Addis Ababa should also develop a stronger consensus on the core tasks that contemporary UN and AU peace operations should be able to undertake. So far, too many peace operations in Africa have involved a mix of different, sometimes contradictory, agendas, including peacekeeping (in its traditional sense), peace consolidation (assisting conflict parties after they have committed to a political settlement), civilian protection, atrocity prevention, counter insurgency, counter terrorism, stabilization, state-building and war-fighting. Not only does each of these tasks require distinct capabilities and training regimes, but also some of them may simply be beyond the capacities of peacekeepers. Certainly, neither the UN nor AU is well suited to fight wars against transnational insurgents or carry out counter terrorism campaigns. The UN and AU should both urgently clarify the doctrine that shall govern their own peace operations and develop their force generation and training requirements accordingly.

3. Incentivize some aspects of force generation. Once the core tasks (and limits) of UN and AU peace operations have been clarified, the authorizing institutions should look to enhance their force generation processes accordingly. Both organizations should clarify whether it is right, and, if so, how to incentivize different types of contributions from their members. Key areas might include incentives for those contributing states that can assume greater than average risk and/or can deploy rapidly into the field. The UN's new Peacekeeping Capabilities Readiness System is already offering premiums in the case of enabling units able to rapidly deploy in $30 / 60 / 90$ days. This approach should be further developed at the UN and also considered by the AU.

4. Develop standards and regularly assess peacekeeper performance. The UN and AU should develop agreed performance standards for peacekeepers deployed by their respective organizations. The UN has taken a major step forward in this regard with the release of its Military Unit Manuals and force assessment guidance. First, therefore, the UN should complete the process of identifying operational standards for the tasks its peacekeepers are expected to perform and 
devise metrics for ensuring that peacekeepers live up to them in the field. This process should be developed for both rank-and-file peacekeepers and senior mission leadership teams. In the immediate term, the effort should focus on implementing the UN's new policy on "Operational Readiness Assurance and Performance Improvement." 27 This awkwardly titled document is arguably one of the most important in the history of peacekeeping because it details how the UN can improve the performance of deployed military units by ensuring a holistic approach by all stakeholders. Specifically, the UN Secretary-General should ensure that the Performance Improvement Cycle described as part of this process is institutionalized, adequately resourced, and routinely carried out for all UN peace operations. This process would also need a policing equivalent. Once the UN's operational standards are clarified and the organization is able to evaluate them in the field, it must ensure that when peacekeepers fail to perform they should be replaced by those who can. The AU should adopt a similar type of policy fit for its own purposes.

5. Ensure sustainable and predictable funding for African peace operations. While the UN system of financing its peace operations works relatively effectively, the same cannot be said for Africanled missions, which have long struggled to find funds. In order to satisfy the approach to funding operations set out in Article 21 of its Peace and Security Council Protocol (2002), ${ }^{28}$ the AU developed a new source of funding for its peace operations that was intended to deliver on its commitment to fund 25 percent of its peace and security activities by $2020 .{ }^{29}$ This took the form of the new AU Peace Fund, launched in late 2018. By early 2020 the Fund had generated over $\$ 100$ million to spend on the AU's peace and security activities. ${ }^{30}$ Despite this significant progress, the AU is still far from financially self-sufficient with regard to peace operations, hence the UN and AU must continue to work out how and when African-led missions can access the UN's assessed peacekeeping contributions.

6. Stop peacekeepers engaging in sexual exploitation and abuse. Finally, all actors engaged in peace operations must ensure that they put a stop to peacekeepers committing sexual exploitation and abuse and hold perpetrators accountable, quickly and transparently. The victims must also be given access to reparations for any crimes committed by international peacekeepers. The most sensible place 
to start is to ensure that the commitments set out in UN Security Council Resolution 2272 (March 11, 2016) are consistently implemented. For the AU, it means implementing its zero-tolerance policy. In this sense, the firing of the UN's head of mission in Central African Republic, General Babacar Gaye, over allegations of sexual exploitation and abuse by peacekeepers there has set an important precedent. The same should apply when UN peacekeepers engage in other types of misconduct, including smuggling and other forms of civilian harm. As Ban Ki-moon noted in his farewell address as UN Secretary-General, these episodes "tarnished the reputation of the United Nations and, far worse, traumatized many people we serve." 31

\section{Notes}

1. Paul D. Williams, "Peace Operations," in The International Studies Encyclopedia, Volume IX, R. A. Denemark (ed.) (Oxford: Blackwell, 2010), 5553.

2. For details, see Paul D. Williams, War and Conflict in Africa, 2nd ed. (Cambridge: Polity, 2016), 279-81.

3. William, War and Conflict in Africa, chapter 10.

4. UN Security Council, Meeting 6153, S.PV/6153 Resumption l (June 29, 2009), p. 3, https://www.securitycouncilreport.org/atf/cf/\%7B6 5BFCF9B-6D27-4E9C-8CD3-CF6E4FF96FF9\%7D/PKO\%20SPV\%206 153\%20Res\%201.pdf.

5. UN Security Council, Meeting 8218, S/PV.8218 (March 28, 2018), p. 3, https://www.securitycouncilreport.org/atf/cf/\%7B65BF CF9B-6D27-4E9C-8CD3-CF6E4FF96FF9\%7D/s_pv_8218.pdf.

6. See Paul D. Williams, Fighting for Peace in Somatia: A History and Analysis of the African Union Mission (AMISOM), 2007-2017 (Oxford: Oxford University Press, 2018).

7. UN General Assembly and Security Council, Report of the Panel on United Nations Peace Operations, A/55/305-S/2000/809, August 21, 2000, https://www.un.org/ruleoflaw/files/brahimi\%20report $\% 20 \mathrm{p}$ eacekeeping.pdf.

8. UN General Assembly and Security Council, Report on the High-Level Independent Panel on Peace Operations on Uniting Our Strengths for Peace: Politics, Partnership, and People, A/70/95-S/2015/446, June 17, 2015, https://www.securitycouncilreport.org/atf/cf/\%7B65BF CF9B-6D27-4E9C-8CD3-CF6E4FF96FF9\%7D/s_2015_446.pdf.

9. See Victoria Holt, Glynn Taylor with Max Kelly, Protecting Civilians in the Context of UN Peacekeeping Operations (New York: UN DPKO/OCHA, 
November 2009) and Jide M. Okeke and Paul D. Williams (eds.), Protecting Civilians in African Union Peace Support Operations: Key Cases and Lessons Learned (South Africa: ACCORD, 2017).

10. UN Security Council, Report of the Independent Inquiry into the Actions of the United Nations During the 1994 Genocide in Rwanda, S/1999/1257, December 16, 1999, https://www.securitycouncilreport. org/atf/cf/\%7B65BFCF9B-6D27-4E9C-8CD3-CF6E4FF96FF9\%7D/ POC\%20S19991257.pdf; UN General Assembly, Report of the SecretaryGeneral Pursuant to General Assembly Resolution 53/35, A/54/549, November 15, 1999, https://www.securitycouncilreport.org/atf/cf/\% 7B65BFCF9B-6D27-4E9C-8CD3-CF6E4FF96FF9\%7D/a_549_1999. pdf; and A/55/305-S/2000/809.

11. UN General Assembly, Evaluation of the Implementation and Results of Protection of Civilians Mandates in United Nations Peacekeeping Operations, A/68/787, March 7, 2014, https://undocs.org/A/68/787.

12. UN Security Council, Resolution 2155, S/RES/2155, May 272014 , https://www.securitycouncilreport.org/atf/cf/\%7B65BFCF9B-6D274E9C-8CD3-CF6E4FF96FF9\%7D/s_res_2155.pdf.

13. See Paul D. Williams, "Protection, Resilience and Empowerment: United Nations Peacekeeping and Violence Against Civilians in Contemporary Warzones," Politics 33, no. 4 (2013): 287-298.

14. See Lisa Hultman, Jacob Kathman, and Megan Shannon, "United Nations Peacekeeping and Civilian Protection in Civil War," American Journal of Political Science 57, no. 4 (2013): 875-891.

15. Holt, Taylor with Kelly, Protecting Civilians in the Context of UN Peacekeeping Operations, 12: 211.

16. UN Security Council, Resolution 2098, S/RES/2098, March 28, 2013, I $12 \mathrm{~b}$.

17. "Principles of UN Peacekeeping," United Nations, accessed January 30, 2020, www.un.org/en/peacekeeping/operations/principles.shtml.

18. A/70/95-S/2015/446, ๆ 122.

19. A/70/95-S/2015/446, I 119.

20. A/70/95-S/2015/446.

21. A/70/95-S/2015/446, I 107.

22. Paul D. Williams with Bellamy, Understanding Peacekeeping, 3rd ed. (Cambridge: Polity, 2010), chapter 12.

23. Adam C. Smith and Arthur Boutellis, "Rethinking Force Generation: Providing for Peacekeeping No. 2," IPI, May 2013, https://www.ipinst. org/wp-content/uploads/publications/ipi_rpt_rethinking_force_gen.pdf.

24. See Williams with Bellamy, Understanding Peacekeeping, chapter 12.

25. See the various reports available at www.providingforpeacekeeping.org.

26. "Conduct in UN Field Missions," United Nations, accessed January 30, 2020, https://conduct.unmissions.org/. 
27. "Operational Readiness Assurance and Performance Improvement," United Nations Department of Peacekeeping Operations, December 2015, http://dag.un.org/bitstream/handle/11176/400699/Policy\%20Oper ational\%20Readiness\%20Assurance\%20and\%20Performance\%20Improve ment\%20Policy.pdf?sequence $=1$ \&isAllowed $=\mathrm{y}$.

28. African Union, Protocol Relating to the Establishment of the Peace and Security Council of the African Union, http://www.peaceau.org/upl oads/psc-protocol-en.pdf.

29. "Securing Predictable and Sustainable Financing for Peace in Africa," $A U$ Peace Fund, August 2016, https://www.peaceau.org/uploads/auhr-pro gress-report-final-020916-with-annexes.pdf.

30. "Peace Fund," African Union, accessed January 20, 2020, https://au. int/en/aureforms/peacefund.

31. Cited in Colum Lynch, "UN Chief Blasts World Leaders in Farewell Address," Foreign Policy, September 20, 2016, http://foreignpolicy.com/ 2016/09/20/un-chief-blasts-world-leaders-in-farewell-address/.

Open Access This chapter is licensed under the terms of the Creative Commons Attribution 4.0 International License (http://creativecommons.org/licenses/ by $/ 4.0 /$ ), which permits use, sharing, adaptation, distribution and reproduction in any medium or format, as long as you give appropriate credit to the original author(s) and the source, provide a link to the Creative Commons license and indicate if changes were made.

The images or other third party material in this chapter are included in the chapter's Creative Commons license, unless indicated otherwise in a credit line to the material. If material is not included in the chapter's Creative Commons license and your intended use is not permitted by statutory regulation or exceeds the permitted use, you will need to obtain permission directly from the copyright holder.

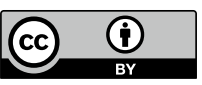

